\title{
光機能材料の新展開 Recent Developments in Optical Materials
}

\author{
田中 勝久 \\ Katsuhisa TANAKA \\ 京都大学 \\ Kyoto University
}

光機能材料はその種類がきわめて豊富です．光機能材料が さまざまな特性を持ち, 多くの領域で実用的に重要であるの は, 光と物質の相互作用に起因する現象が多様であり, 対象 となる光の波長（エネルギー）の範囲がきわめて広いことが その一因です。たとえば，情報・通信の分野で光を信号とし て利用する一つのシステムを考えてみても，光源，導波路， 光変調素子, 光検出器, 光記録媒体など, さまざまな材料や デバイスが必要であり，光信号のマニピュレーションを効率 よく実行する上で不可欠な優れた特性を示す新たな材料の開 発や, 潜在的に機能を有する新物質の探索がますます重要に なっています。また, 人工的な構造に基づいて特異な光学現 象を導くフォトニック結晶やメタマテリアルなどの材料がす でに市民権を得ているほか，近年は，ナノ構造を有する金属 の局在型表面プラズモンを利用した光機能の高効率化に関す る研究が活発に行われています。プラズモニクスの分野では ナノスケールの構造を持つ金属材料を高い精度で製造する技 術が求められ，ナノ治金学とも呼ぶべき領域が開拓されつつ あります，光技術は上記の情報・通信のみならず, 計測, 加 工，環境，医療，エネルギー産業などあらゆる分野に関連す るため, その基本となる光機能材料の創出がもたらす影響の 大きさは言を俟たないところです，本講演特集は，進展が著 しい光機能材料の研究・開発に関する情報交換を行い, 材料 の新たな展開を探ることを目的として設けられました。

本特集では，合計で 11 件の講演が，3つのセッションに おいて行われました。

最初のセッションでは, 赤外透過 $\mathrm{GeS}_{2}-\mathrm{Sb}_{2} \mathrm{~S}_{3}$ 系ガラスへの $\mathrm{ZnS}$ 添加が結晶化に及ぼす影響ならびに酸化物が誘起する微
視的不均一性, $\mathrm{Al}_{2} \mathrm{O}_{3}-\mathrm{Y}_{2} \mathrm{O}_{3}$ ガラス内部へのレーザー照射と光 誘起結晶成長，非晶質金属水酸化物を前駆体とした $\mathrm{ZnGa}_{2} \mathrm{O}_{4}$ の表面塩基特性と $\mathrm{CO}_{2}$ 光還元触媒特性についての研究成果 が発表されました。

第 2 のセッションでは, フェムト秒レーザー照射による黒 鉛化を抑制したダイヤモンド内部への NV 中心形成，単結晶 Si の直接通電加熱による低温変形メカニズム, 窒化チタン ナノシリンダーアレイへの誘電体層の被覆による耐熱性の向 上, $\mathrm{Al}$ ナノ周期構造による $\mathrm{Fe}$ の磁気光学効果の増強に関す る発表がありました

最後のセッションでは，プラズモニックおよび非プラズモ ニック材料から成るナノシリンダーアレイの発光増強効果の 比較，細孔修飾した配向性金属有機構造体薄膜におけるゲス 卜分子の配列制御と光応答, $\mathrm{Eu}^{2+}$ およ゙ $\mathrm{Eu}^{3+}$ がそれぞれ異 なる結晶相に添加された結晶化ガラスの作製と白色 LED へ の展開に関する発表が行われました。

以上, 今回の講演特集では, 赤外透過ガラスの基礎物性, 赤外用レンズとしての利用を目的とした $\mathrm{Si}$ の加工, 超短パ ルスレーザーを用いた物質の加工と蛍光体やセンサーへの応 用，酸化物の表面活性化と光触媒特性，金属有機構造体をホ ストとして利用する蛍光分子の発光特性, 金属ナノ周期アレ イの構築とプラズモニクス材料としての応用, 白色 LED 用 の新たな蛍光体の開発といった多岐にわたる研究成果の報告 がなされ，いずれの発表においても活発な質疑応答が展開さ れました．最先端の貴重な研究の結果を報告していただいた 方々，ならびに活発な討論に加わっていただいた方々に，本 講演特集の企画者としてあらためて御礼申し上げる次第です。 